MEDFARM: Jurnal Farmasi dan Kesehatan, Vol.10, No.2, Des 2021, Hal, 29-38

e-ISSN : 2715-9957

p-ISSN: $2354-8487$

\title{
UJI AKTIVITAS EKSTRAK AIR LIMBAH KOKON ULAT SUTERA (Bombyx mori L.) SEBAGAI PELEMBAB
}

\author{
Maria Ulfa, Reny Syahruni, Krisniati Deppong \\ Sekolah Tinggi Ilmu Farmasi Makassar \\ Email : mariaulfaadam@gmail.com
}

\begin{abstract}
ABSTRAK
Salah-satu masalah kulit yang sering dikeluhkan oleh masyarakat adalah kulit kering. Pelembab dapat meningkatkan hidrasi kulit dan dapat berfungsi sebagai perawat tambahan dalam kondisi dermatologis. Protein kokon ulat sutera (Bombyx mori L.) terutama serisin telah diketahui memiliki efek sebagai pelembab kulit. Penelitian ini bertujuan untuk mengetahui efek ekstrak air limbah kokon ulat sutera sebagai pelembab yang diperoleh melalui teknik rebusan dan mengevaluasi keamanan penggunaannya terhadap efek iritasi pada kulit. Uji aktivitas dilakukan terhadap 15 sukarelawan yang dibagi menjadi 3 kelompok yaitu kelompok ekstrak kokon, kelompok gliserin (kontrol positif) dan kelompok tanpa perlakuan (kontrol negatif) dengan pengamatan pada menit ke-0 hingga menit ke-30 selama 7 hari. Hasil uji aktivitas kelembaban menunjukkan bahwa ekstrak kokon dan gliserin dapat meningkatkan kelembaban kulit dengan nilai persentase kadar 44-53\% untuk ekstrak kokon dan gliserin $52-54 \%$ serta kontrol negatif $33-40 \%$. Ekstrak air limbah kokon ulat sutera yang diperoleh melalui teknik rebusan memiliki aktivitas sebagai pelembab kulit dan tidak menyebabkan reaksi iritasi kulit.
\end{abstract}

Kata kunci : Kokon ulat sutera, serisin, kelembaban kulit

\begin{abstract}
One of the skin problems that people often complain about is dry skin. Moisturizers can increase skin hydration and can serve as a supplementary nurse in dermatological conditions. Silkworm cocoon protein (Bombyx mori L.) especially sericin has been known to have a skin moisturizing effect. This study aims to determine the effect of silkworm cocoon wastewater extract as a moisturizer obtained through the decoction technique and to evaluate the safety of its use against the irritating effect on the skin. The activity test was carried out on 15 volunteers who were divided into 3 groups, namely the cocoon extract group, the glycerin group (positive control), and the untreated group (negative control) with observations at 0 to 30 minutes for 7 days. The results of the moisture activity test showed that cocoon and glycerin extracts could increase skin moisture with a percentage value of $44-53 \%$ for cocoon and glycerin extract $52-54 \%$ and $33-40 \%$ negative control. The silkworm cocoon wastewater extract obtained through the decoction technique has activity as a skin moisturizer and does not show an irritating effect.
\end{abstract}

Key words: Silkworm cocoon, sericin, skin moisture

\section{PENDAHULUAN}

Kulit merupakan jaringan terluar dari tubuh yang memiliki fungsi utama untuk melindungi organisme terhadap efek lingkungan yang tidak diinginkan. 
MEDFARM: Jurnal Farmasi dan Kesehatan, Vol.10, No.2, Des 2021, Hal, 29-38

e-ISSN : 2715-9957

p-ISSN: 2354-8487

Akibatnya, orang sangat sadar dan sensitif terhadap penampilan kulit mereka, sehingga penampilan kulit menjadi subjek yang sangat diminati di berbagai bidang ilmu dan teknologi (Igarashi, et al., 2005; Dominguez-Delgado, et al., 2010). Salah satu masalah kulit yang banyak dikeluhkan oleh masyarakat adalah kulit kering.

Hidrasi kulit sangat penting untuk kesehatan kulit, dimana kulit yang dilembabkan umumnya dianggap sehat dan tampak sehat (Jiang \& DeLaCruz, 2011). Hidrasi kulit didefenisikan sebagai kandungan air dari epidermis dan dermis. Kadar air dapat bervariasi tergantung pada berbagai faktor seperti lokasi kulit, kedalaman kulit, indeks massa tubuh, usia, jenis kelamin, jam diurnal, musim dan iklim (Guzmán-Alonzo \& Cortazár, 2016). Pelembab dapat meningkatkan hidrasi kulit dan dapat berfungsi sebagai perawatan tambahan dalam kondisi dermatologis seperti xerosis, psoriasis vulgaris, atopic dermatitis dan ichthyosis, dimana kulit kering terlibat (Nogueira, et al., 2010).

Penggunaan beberapa bahan alam dari tanaman seperti rumput laut, lidah buaya, teh hijau telah dilaporkan sebagai alternatif pelembab kulit (Choi, et al., 2013; Surjushe, et al., 2008; Stallings, et al., 2009). Selain bahan alam dari bagian tanaman, produk dari serangga dan hewan juga memiliki potensi sebagai pelembab alami. Beberapa artikel publikasi memberikan ulasan terkait manfaat protein kokon ulat sutera (Bombyx mori L.) terutama serisin sebagai pelembab kulit (Kunz, et al., 2016; Padamwar \& Pawar, 2004; Padamwar, et al., 2006). Secara empiris masyarakat Soppeng (salah satu daerah pengolahan sutera di Sulawesi Selatan) menggunakan limbah kokon ulat sutera untuk perawatan wajah atau sebagai pelembab dengan cara kokon dibasahi dengan air kemudian dioleskan pada wajah. Namun sejauh ini, pemanfaatan kokon dengan teknik tersebut belum diketahui pembuktiannya secara ilmiah.

Serisin dari kokon ulat sutera merupakan glikoprotein globular yang larut dalam air (Tao, et al., 2005), karena itu proses ekstraksinya dapat menggunakan air atau etanol-air dalam berbagai metode dengan teknik degumming (penguraian serat sutera/fibroin dari bahan perekatnya/serisin) melalui metode ekstraksi tekanan tinggi dan suhu tinggi, larutan asam atau basa, atau ekstraksi enzim (Wu, et al., 2007; Zaradina, 2016; Aramwit, et al., 2010). Penggunaan metode- 
MEDFARM: Jurnal Farmasi dan Kesehatan, Vol.10, No.2, Des 2021, Hal, 29-38

e-ISSN : 2715-9957

p-ISSN: 2354-8487

metode ekstraksi tersebut melibatkan peralatan laboratorium dan tahapan yang rumit, sehingga susah untuk diaplikasikan pada masyarakat umum.

Pemanfaatan ekstrak kokon dengan teknik ekstraksi yang telah teruji secara ilmiah untuk menjamin efektivitas dan keamanan menjadi satu tantangan yang mendorong peneliti untuk melakukan uji aktivitas dari ekstrak kokon yang diperoleh dengan teknik sederhana seperti rebusan sehingga memudahkan masyarakat dalam penggunaannya.

\section{METODOLOGI PENELITIAN}

\section{Waktu dan tempat penelitian}

September 2020 - Juli 2021 di Laboratorium Biologi Farmasi dan Laboratorium Farmasetika Sekolah Tinggi Ilmu Farmasi Makassar

\section{Metode Ekstraksi}

Proses ekstraksi kokon dilakukan dengan cara menimbang kokon sebanyak 10 gram, lalu dimasukkan ke dalam gelas kimia dan ditambahkan air suling 250 $\mathrm{mL}$. Campuran dipanaskan pada suhu $50^{\circ} \mathrm{C}$ selama 1 jam. Filtrat dipisahkan dari residu dengan cara penyaringan menggunakan kertas saring (Putri, R. A., 2019).

\section{Penyiapan Sukarelawan Uji}

Penentuan sukarelawan dipilih dengan kriteria inklusi/eksklusi. Kriteria inklusi meliputi sukarelawan wanita dan pria berusia antara 20-35 tahun dengan kondisi kesehatan yang baik, dan menandatangani informed consent statement. Kriteria eksklusi meliputi riwayat eksim, psoriasis dalam waktu 6 bulan sebelum penelitian, reaksi alergi kulit 30 hari sebelum penelitian, wanita hamil atau menyusui, menjalani operasi kosmetik dalam 12 bulan sebelumnya, perawatan terbaru dengan produk-produk pelembab, penyakit atau kondisi dermatologis yang dapat mengganggu fungsi neuromuskuler seperti miastenia gravis, pengobatan dengan obat topikal atau sistemik yang dapat memengaruhi hasil tes. Jumlah sukarelawan sebanyak 15 orang yang dibagi dalam 3 kelompok perlakuan. Selama interval 7 hari sebelum awal tes, subjek tidak menggunakan produk kosmetik (Choi, et al. 2013; Leelapornpisid, et al., 2014).

\section{Uji Kelembaban Ekstrak Pada Manusia}

Sebelum mengaplikasikan sampel uji, para sukarelawan uji diaklimatisasi/diistirahatkan sejenak selama 30 menit pada suhu kamar untuk 
MEDFARM: Jurnal Farmasi dan Kesehatan, Vol.10, No.2, Des 2021, Hal, 29-38

e-ISSN : 2715-9957

p-ISSN: 2354-8487

memungkinkan adaptasi kulit. Sampel diaplikasikan pada lengan atas kanan dan kiri bagian dalam di area 3,8 x 3,8 cm. Kapasitas pelembab dari ekstrak diuji pada kulit sukarelawan manusia dan dibandingkan dengan gliserin 5\% (kontrol positif) dan pada kulit yang tidak diberi apapun (kontrol negatif). Jumlah ekstrak dan gliserin yang diaplikasikan sekitar 0,2 ml. Kadar kelembaban diukur menggunakan skin analyzer sebelum dan setelah pengaplikasian sampel uji pada 10, 15, dan 30 menit pada sore hari selama 7 hari berturu-turut (Leelapornpisid, et al., 2014).

\section{Uji Iritasi}

Uji iritasi dilakukan dengan metode patch test (tempel terbuka) untuk memastikan keamanan ekstrak air limbah kokon ulat sutera pada kulit manusia. Patch dibuka setelah 48 jam aplikasi. Tanda iritasi (eritema dan edema) diamati pada bagian kulit yang diaplikasikan sampel uji setelah 6 jam patch dibuka (Choi et al. 2013).

Penilaian derajat iritasi dilakukan dengan cara memberi skor 0 sampai 4 tergantung tingkat keparahan reaksi eritema dan edema pada kulit yang terlihat (Ali, et al., 2013):

1. Eritema
a. Tanpa eritema : 0
b. Sangat sedikit eritema : 1 (diameter $<25 \mathrm{~mm}$ )
c. Eritema jelas terlihat : 2 (diameter 25,1-30 mm)
d. Eritema sedang : 3 (diameter 30,1-35 mm)
e. Eritema berat : 4 (gelap merah dengan membentuk eskar, Diameter $>35$ $\mathrm{mm})$

2. Edema
a. Tanpa edema : 0
b. Sangat sedikit edema : 1 (hampir tidak terlihat)
c. Edema tepi berbatas jela : 2 (ketebalan $<1 \mathrm{~mm}$ )
d. Edema sedang : 3 (tepi naik $\pm 1 \mathrm{~mm}$ )
e. Edema berat : 4 (tepi naik lebih dari $1 \mathrm{~mm}$ dan meluas keluar daerah pejanan).
Masing-masing bahan uji dihitung indeks iritasi dengan menggunakan rumus sebagai berikut: 
MEDFARM: Jurnal Farmasi dan Kesehatan, Vol.10, No.2, Des 2021, Hal, 29-38

e-ISSN : 2715-9957

p-ISSN: 2354-8487

Indeks Iritasi:

$$
=\frac{(\text { skor eritema } 24+48+72 \text { jam })+(\text { skor edema } 24+48+72 \text { jam })}{\text { jumlah sukarelawan }}
$$

Indeks iritasi yang diperoleh dibandingkan dengan skor derajat iritasi untuk mengetahui keparahan reaksi iritasi (ISO., 2010) :
a. Tidak mengiritasi :0,0,
b. Sangat sedikit iritasi :0,1-0,4,
c. Sedikit iritasi :0,41-1,9,
d. Iritasi sedang :2,0-4,9,
e. Iritasi parah $\quad: 5,0-8,0$.

\section{HASIL DAN PEMBAHASAN}

Pemanfaatan limbah kokon ulat sutera Bombyx mori L. yang umumnya tidak digunakan oleh masyarakat menjadi fokus utama dalam latar belakang penelitian ini. Protein serisin yang terkandung dalam kokon memiliki beragam manfaat termasuk untuk perawatan kulit. Pada penelitian ini hasil rebusan limbah kokon diuji aktivitasnya sebagai pelembab kulit pada manusia.

Metode rebusan digunakan dalam proses ekstraksi dengan pertimbangan bahwa rebusan merupakan metode yang dapat secara langsung diaplikasikan oleh masyarakat karena alat yang digunakan sangat sederhana. Perebusan menggunakan air sebagai penyari karena murah, mudah diperoleh, stabil, tidak beracun, tidak mudah menguap. Tao et al. (2005) menyatakan bahwa serisin dari kokon ulat sutera merupakan glikoprotein globular yang larut dalam air.

Uji aktivitas ekstrak air kokon pada sukarelawan uji menggunakan 15 sukarelawan yang telah memenuhi kriteria inklusi dan ekslusi. Selama 7 hari dilakukan pemeriksaan kadar kelembaban kulit sukarelawan pada awal sebelum aplikasi dan setelah aplikasi ekstrak air kokon ulat sutera. Sebagai kontrol pembanding digunakan gliserin yang telah diketahui memiliki efek sebagai pelembab. Gliserin bersifat humektan kuat, mempunyai kemampuan menyerap air (NMF), terbuat dari asam amino, berfungsi menstabilkan dan memberi air pada membran sel (Black et al., 2005). 
MEDFARM: Jurnal Farmasi dan Kesehatan, Vol.10, No.2, Des 2021, Hal, 29-38

e-ISSN : 2715-9957

p-ISSN: 2354-8487

Kelembaban kulit diukur dengan menggunakan skin analyzer dengan parameter: kulit kering 0-29\%, kulit normal 30-50\% dan kulit lembab 51-100\% (Manggau, dkk., 2017).

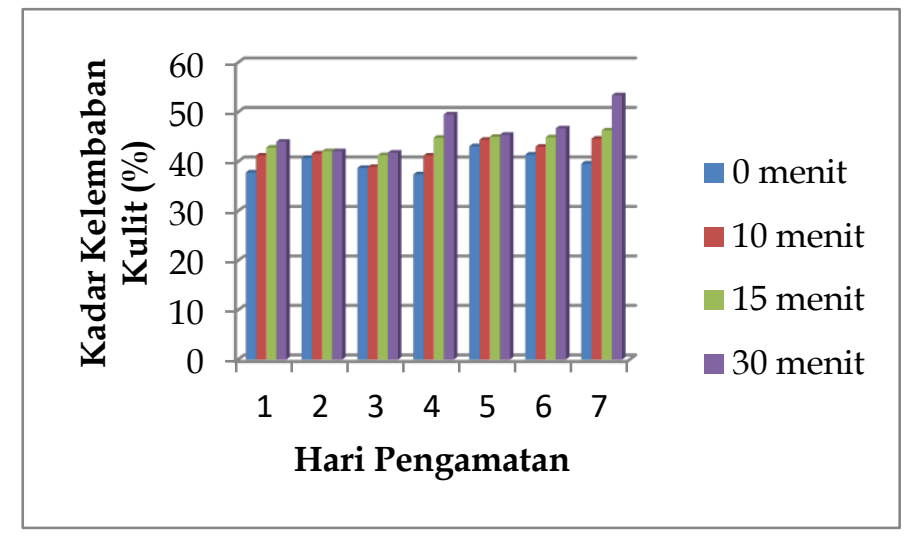

Gambar 1. Hasil pengukuran kadar kelembaban kulit dengan menggunakan ekstrak air limbah kokon ulat sutera (Bombyx mori L.).

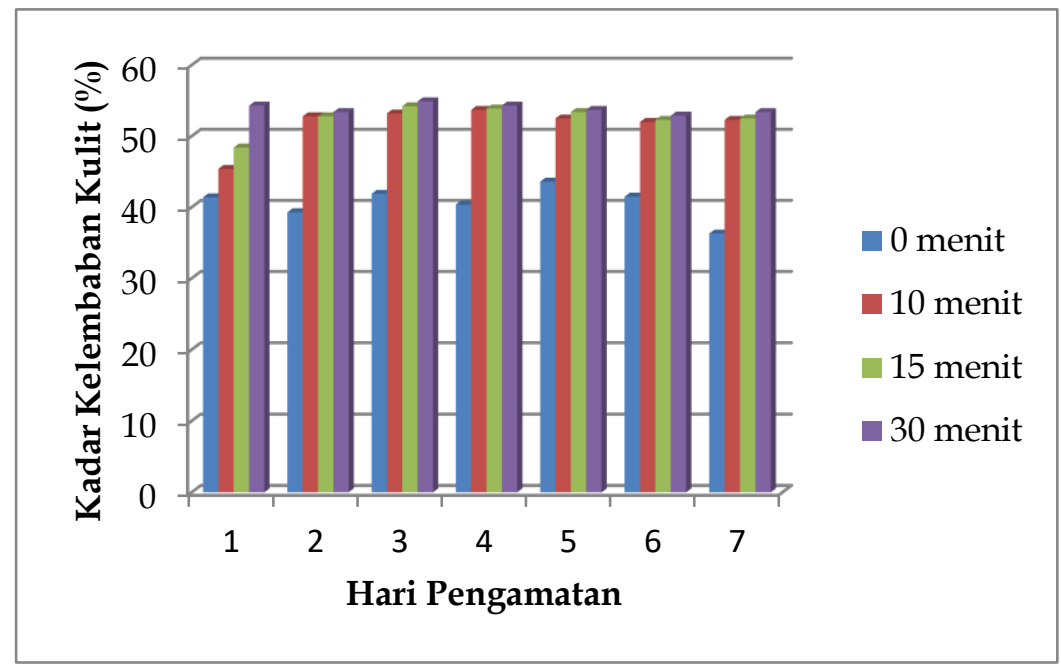

Gambar 2. Hasil pengukuran kadar kelembaban kulit dengan menggunakan Gliserin 5\%.

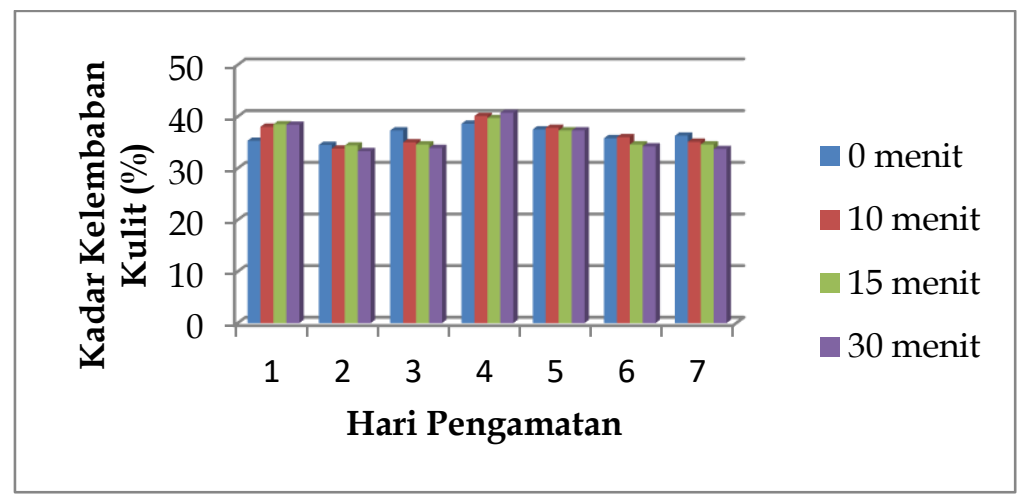


MEDFARM: Jurnal Farmasi dan Kesehatan, Vol.10, No.2, Des 2021, Hal, 29-38

e-ISSN : 2715-9957

p-ISSN: 2354-8487

Gambar 3. Hasil pengukuran kadar kelembaban kulit pada kontrol negatif (tanpa perlakuan).

Pada gambar 1, memperlihatkan kadar kelembaban kulit sukarelawan yang meningkat dari menit ke-0 (sebelum perlakuan) hingga menit ke-30 pada pengamatan setiap hari setelah pemberian ekstrak, namun jika dilihat dari penggunaan setiap harinya pada menit ke-30 persentase kadar kelembaban kulit naik turun dengan nilai kadar berada pada kisaran 44-53\%. Serupa dengan hasil pada pemberian ekstrak kokon, pemberian gliserin 5\% juga menunjukkan peningkatan dari menit ke-0 hingga menit ke-30, dan tingkat kelembaban kulit dari hari ke-1 hingga hari ke-7 juga naik turun dengan kisaran persentase kelembaban 52-54\% (gambar 2). Meskipun kadar yang ditunjukkan pada pemberian ekstrak kokon dan gliserin mengalami peningkatan dan penurunan, namun perlakuan keduanya masih dapat dianggap memberikan pengaruh terhadap peningkatan kelembaban kulit bila dibandingkan dengan kontrol negatif yang tidak menunjukkan peningkatan kelembaban pada kulit sukarelawan sejak pengukuran awal hingga perlakuan pada hari ke-7 dimana persentase kelembaban kulit berada pada 33-40\%. Nilai persentase kelembaban pada kontrol negatif lebih rendah dibandingkan kelembaban kulit pada pemberian ekstrak kokon dan gliserin (gambar 3).

Serisin merupakan bahan yang memiliki kemampuan untuk perbaikan kulit (Su, et al., 2019). Menurut Padamwar, dkk. (2005), serisin dapat mengurangi impedansi serta meningkatkan level hidroksiprolin dan hidrasi sel-sel epidermis. Peningkatan hidrasi disebabkan oleh efek oklusif dari serisin yang mencegah kehilangan air transepidermal. Variasi kandungan asam amino berperan dalam retensi air yang dapat mengurangi terjadinya penguapan air (Su, et al., 2019).

Hasil uji iritasi .kulit penggunaan ekstrak air limbah kokon ulat sutera (Bombyx mori L.) dapat dilihat pada tabel 1 sebagai berikut.

Tabel 1 Data Uji Iritasi Kulit Pengunaan Ekstrak Air Limbah Kokon Ulat Sutera (Bombyx mori L.)

\begin{tabular}{ccc}
\hline Sukarelawan & Eritema & Edema \\
\hline S1 & 0 & 0 \\
S2 & 0 & 0 \\
S3 & 0 & 0 \\
S4 & 0 & 0 \\
S5 & 0 & 0
\end{tabular}


MEDFARM: Jurnal Farmasi dan Kesehatan, Vol.10, No.2, Des 2021, Hal, 29-38

e-ISSN : 2715-9957

p-ISSN: 2354-8487

\begin{tabular}{cll} 
S6 & 0 & 0 \\
S7 & 0 & 0 \\
S8 & 0 & 0 \\
\hline Indeks iritasi & 0 & 0 \\
\hline
\end{tabular}

Keterangan :

$S$ : Sukarelawan

Uji iritasi dilakukan untuk mengetahui efek iritasi dari ekstrak air limbah kokon ulat sutera (Bombyx mori L.) setelah diaplikasikan pada kulit, untuk mengetahui tingkat keamanannya sebelum digunakan oleh masyarakat luas. Iritas menurut Dewantara et al., (2015) merupakan gejala inflamasi yang terjadi pada kulit atau membran mukosa akibat penggunaan berulang atau berkepanjangan suatu bahan. Faktor yang dapat mempengaruhi iritasi pada kulit yaitu permukaan kulit, lamanya bahan bersentuhan dengan kulit, dan konsentrasi bahan.

Uji iritasi dilakukan pada pengamatan jam ke-48 setelah diberikan perlakuan (ekstrak kokon) dengan mengamati reaksi kulit yang timbul berdasarkan dua parameter utama yaitu tingkat eritema (reaksi kemerahan) dan tingkat udema (bengkak). Tabel 1 menunjukkan tidak terlihat adanya efek samping berupa kemerahan dan gatal-gatal pada kulit yang diberi nilai indeks iritasi 0 (kategori tidak mengiritasi).

\section{Kesimpulan}

Berdasarkan hasil yang diperoleh dapat disimpulkan bahwa Ekstrak air limbah kokon ulat sutera yang diperoleh melalui teknik rebusan memiliki aktivitas sebagai pelembab kulit. Ekstrak air limbah kokon ulat sutera tidak menyebabkan reaksi iritasi kulit.

\section{Daftar Pustaka}

Aramwit, P., Kanokpanont, S., Nakpheng, T., \& Srichana, T., 2010. The Effect of Sericin From Various Extraction Methods on Cell Viability and Collagen Production. International Journal of Molecular Sciences, 11(5): 2200-2211, doi: 10.3390/ijms11052200.

Ali, A., Akhtar, N., Mumtaz, A.M., Khan, M.S., Iqbal, F.M., \& Zaidi, S.S., 2013. In Vivo Skin Irritation Potential of a Cream Containing Moringa oleifera Leaf Extract. African Journal of Pharmacy and Pharmacology, 7(6): 289-293. 
MEDFARM: Jurnal Farmasi dan Kesehatan, Vol.10, No.2, Des 2021, Hal, 29-38

e-ISSN : 2715-9957

p-ISSN: 2354-8487

Black, D., Josse, G., Rouvrais, C. \& Lagarde, J. M. 2005. Skin Care Products for Normal, Dry and Greasy Skin. In: Baran, R., Maibach, H. I., Taylor \& Francis (eds.). Textbook of Cosmetic Dermatology. 3rd ed. USA: Boca Raton.

Choi, J.S., et al., 2013. Effects of Seaweed Laminaria japonica Extracts on Skin Moisturizing Activity In Vivo. Journal of Cosmetic Science, 64(3): 193-205.

Dewantara Igna, Prasetia Ignja, Putri Nntan, Arsana Damips, Prabayanti Npm. 2015. Uji eritema dan edema secra in vivo pada natrium lauril sulfat $10 \%$. Jurnal Farmasi Udayana. 4(2):25-28.

Domínguez-Delgado, C.L., Rodríguez-Cruz, I.M., \& López-Cervantes, M., 2010. The Skin: A Valuable Route for Administration of Drugs, in EscobarChávez, J.J. \& Merino, V., Current Technologies to Increase The Transdermal Delivery of Drugs: 1-22

Guzmán-Alonzo, M. \& Cortazár, T.M., 2016. Water Content at Different Skin Depths and The Influence of Moisturizing Formulations. Household and Personal Care Today, 11(1): 35-40.

Igarashi, T., Nishino, K., \& Nayar, S.K., 2007. The Appearance of Human Skin: A Survey. Foundations and Trends ${ }^{\circledR}$ in Computer Graphics and Vision, 3(1): 1-95, doi: 10.1561/0600000013.

Internasional standart ISO 10993-10. 2010. Bioligical Evaluation of Medical Device, Part 10-Test for Irritation and Delayed-Type Hypersensitivity, Second Edition.

Jiang, Z.X. \& DeLaCruz, J., 2011, Appereance Benefits of Skin Moisturization, Skin Research and Technology, 17(1): 51-55, doi: 10.1111/j.16000846.2010.00462.x

Kunz, R.I., Brancalhão, R.M.C., Ribeiro, L.D.F.C., \& Natali, M.R.M., 2016. Review Article Silkworm Sericin: Properties and Biomedical Applications, BioMed Research International, 817570119: 1-19.

Leelapornpisid, P., Mungmai, L., Sirithunyalug, B., Jiranusornkul, S., \& Peerapornpisal, Y., 2014. A Novel Moisturizer Extracted from Freshwater Macroalga [Rhizoclonium hieroglyphicum (C.Agardh) Kützing] for Skin Care Cosmetic, Chiang Mai Journal of Science, 41(5.2): 1195-1207.

Manggau, M. A., Riska D., dan Lukman M., 2017. Uji Efektivitas Kelembaban Sabun Transparan Ekstrak Rumput Laut Cokelat (Sargassum Cristaefolium C. Agardh) dengan Variasi Konsentrasi Sukrosa. Journal of Pharmaceutical and Medicinal Sciences 2(1): pp 21-26.

Nogueira, A., Sidou, F., \& Brocard, S., 2011. Effect of A New Moisturizing Lotion on Immediate and Cumulative Skin Hydration: Two Randomized, IntraIndividual, Vehicle and Comparator Controlled Studies. Journal of Dermatological Treatment, 22(4): 221-225, doi: 10.3109/09546631003762647. 
MEDFARM: Jurnal Farmasi dan Kesehatan, Vol.10, No.2, Des 2021, Hal, 29-38

e-ISSN : 2715-9957

p-ISSN: 2354-8487

Padamwar, M.N. \& Pawar, A.P., 2004. Silk Sericin and Its Applications: A Review, Journal of Scientific \& Industrial Research, 63:323-329.

Padamwar, M.N., Atmaram, P.P., Aarti, V.D. And Mahadik., 2005. Silk Sericin As A Moisturizer: An In Vivo Study. Journal of Cosmetic Dermatology, 4:250257.

Padamwar, M.N., Pawar, A.P., Daithankar, A.V., \& Mahadik, K.R., 2006. Silk Sericin As A Moisturizer: An In Vivo Study. Journal of Cosmetic Dermatology, 4(4): 250-257, doi: 10.1111/j.1473-2165.2005.00200.x

Putri, R. A., 2019. Pengaruh Variasi Konsentrasi VPA dan Karbopol 940 Terhadap Sifat Fisik Masker Gel/Peel Off dari Liofilisat Limba Kokon (Bombyx mori L.) Makassar. Sekolah Tinggi Ilmu Farmasi Makassar.

Stallings, A.F. \& Lupo, M.P., 2009. Practical Uses of Botanicals in Skin Care, The Journal of Clinical and Aesthetic Dermatology, 2(1): 36-40.

Su, D., Shenglong, D., Weiliang S., Xuefeng H. and Libo, J., 2019. Bombyx mori Silk-based Materials With Implication In Skin Repair: Sericin Versus Regenerated Silk Fibroin, Journal of Biomaterials Applications 0(0) 1-11. DOI: $10.1177 / 0885328219844978$.

Surjushe, A., Vasani, R., \& Saple, D.G., 2008, Aloe Vera: A Short Review, Indian Journal of Dermatology, 53(4): 163-166, doi: 10.4103/0019-5154.44785.

Tao, W., Li, M., \& Xie, R., 2005, Preparation and Structure of Porous Silk Sericin Materials, Macromolecular Materials and Engineering, 290(3): 188-194, doi: 10.1002/mame.200400306.

Wu, J.H., Wang, Z., \& Xu, S.Y., 2007, Preparation and Characterization of Sericin Powder Extracted From Silk Industry Wastewater, Food Chemistry, 103(4): $1255-1262$.

Zaradina, S., 2016. Ekstraksi Srisin Kokon Bombyx mori L. Secagai Bahan Aktif Krim Penyembuh Luka, Skripsi, Departemen Produksi dan Teknologi Peternakan Fakultas Peternakan Institut Pertanian Bogor, Bogor. 